\title{
NA LEI E NAS ESCOLAS: DIFERENTES ASPECTOS DO ENSINO RELIGIOSO NO ESTADO DO RIO DE JANEIRO
}

\author{
Luiz Guilherme Braga*
}

\begin{abstract}
Resumo: Este artigo propõe uma discussão sobre a relação entre religião e modernidade a partir dos debates gerados pela implantação do ensino religioso em colégios públicos de ensino médio do Estado do Rio de Janeiro. Foi realizado, durante um ano, o acompanhamento de aulas de ensino religioso junto a dois professores de um colégio estadual da cidade do Rio de Janeiro. $\mathrm{O}$ acompanhamento do processo de implantação da lei e o trabalho etnográfico dentro da escola proporcionam construir uma nova relação entre religião e espaço público, na qual é possível compreender e aceitar a presença e atuação da religião na esfera pública de um Estado laico sem que isso cause a impressão de que a religião está fora de seu lugar.
\end{abstract}

Palavras-chave: Religião, modernidade, espaço público, ensino religioso.

\begin{abstract}
This article proposes a discussion about the relation between religion and modernity, taking into consideration the debates that arose during the implantation of religious teaching in public high schools in the State of Rio de Janeiro. During one year an ethnographic work was made in a public high school in the city of Rio de Janeiro. The process of implantation of the religious teaching law and the ethnographic work inside a public school allow us to build a new relation between religion and the public sphere, in which it is possible to understand and accept the religion in the public without the common impression that religion is out of place.
\end{abstract}

Keywords: Religion, modernity, public sphere, religious teaching.

\section{O ENSINO RELIGIOSO NA LEI E O ENSINO RELIGIOSO NAS ESCOLAS}

Este trabalho visa apresentar os principais aspectos da pesquisa de mestrado que desenvolvi sobre a questão do ensino religioso nas escolas públicas do Estado do Rio de Janeiro. Procurarei fazer um relato sobre a implantação da lei de ensino religioso, sobre o trabalho etnográfico em uma escola estadual do Rio de Janeiro e, também, apresentar e discutir alguns autores que nos ajudam a pensar a respeito do papel que a religião pode desempenhar no espaço público.

A relação entre religião e escola pública normalmente gera preocupações e polêmica em muitos países de regime democrático. Seja por causa de símbolos religiosos, como o caso francês dos véus usados por alunas secundaristas, seja em virtude da luta de criacionistas pela exclusão do evolucionismo de Darwin das aulas de ciências, ou devido ao ensino religioso na grade curricular dos colégios, a religião na escola pública pode provocar reações diversas, geralmente polarizadas, de apoio ou não

\footnotetext{
* $\quad$ Mestre em sociologia com ênfase em antropologia (PPGSA-UFRJ). Doutorando no Programa de Pós-Graduação em Antropologia Social da Universidade Federal do Rio Grande do Sul (UFRGS).
} 
a sua presença. Se a interação entre religião e espaço público, de uma forma geral, incomoda graças à noção enraizada de que o Estado é laico e desvinculado de qualquer crença religiosa, sua atuação regular dentro dos colégios causa ainda maior inquietação, pois se insere em um ambiente que proporciona formação às crianças e adolescentes. A questão é delicada, pois, dada a natureza das escolas de exercer influência sobre os alunos e de prepará-los para a inserção social (Durkheim, 1978), qualquer mudança curricular, não apenas a inclusão de aulas de religião, pode alterar significativamente a formação e o pensamento de toda uma geração que, em curto período de tempo, será adulta e estará no mercado de trabalho e no comando de um país. Desta maneira, quando a proposta é trazer "oficialmente" a religião para dentro da escola, muitas pessoas se posicionam avessas a esta idéia e um amplo leque de questões como relação entre religião e modernidade, espaço público, escola e Estado laico, tolerância e respeito à pluralidade, é levantado para se argumentar a favor ou contra esta relação.

Em 2004, o Estado do Rio de Janeiro começou a oferecer em seus colégios públicos aulas de ensino religioso dentro da grade horária regular e, por isso, desde o projeto de lei do ex-deputado estadual Carlos Dias, o tema suscita questões e debates que mobilizam diferentes atores sociais, como os governos que implantaram o ensino religioso, os deputados que aprovaram a lei, a sociedade civil, meios de comunicação, entidades religiosas, estudiosos, etc. Amparada pela legislação federal brasileira que prevê o ensino religioso e seu custeio com verbas públicas, a lei estadual 3459 trouxe para dentro das escolas quinhentos professores de ensino religioso contratados a partir de um concurso que contou com 3154 candidatos. Dessas quinhentas vagas abertas, 342 foram destinadas aos professores católicos, 132 aos evangélicos e 26 aos professores dos demais credos (espiritismo, judaísmo, umbanda, etc). Segundo a secretaria estadual de educação, esta divisão foi feita com base em uma pesquisa que buscava levantar a religião dos alunos, que chegou ao seguinte resultado: $65 \%$ católicos, $25 \%$ evangélicos, 5\% espíritas e outras crenças e 5\% sem religião (Giumbelli e Carneiro, 2004).

A lei do deputado Carlos Dias sofreu críticas em todas as etapas de sua implantação. Ainda como projeto e antes da votação na Assembléia Legistativa do Rio de Janeiro (ALERJ), parte dos católicos, evangélicos e espíritas rejeitaram a idéia de ensinar religião nos colégios estaduais. No entanto, os ex-governadores Anthony Garotinho e Rosinha Matheus trabalharam para que o projeto fosse votado e virasse lei estadual. Em 2003, surgiu uma proposta de lei alternativa, do deputado do petista Carlos Minc, que propunha o modelo interconfessional de ensino religioso, o qual não 
separaria os alunos por credo nas aulas. Aprovado na ALERJ, o projeto de Minc foi vetado pela ex-governadora Rosinha. O projeto de Carlos Dias virou lei, estabelecendo o modelo confessional, que define que as aulas serão ministradas por credo religioso e que os alunos, que têm o direito à matrícula facultativa, poderão freqüentar os cursos que correspondam a sua religião, no caso de maiores de 16 anos, ou a religião de seus pais. Estabeleceu-se ainda que as escolas têm a obrigação de oferecer uma atividade alternativa para os alunos que optarem por não participar das aulas de ensino religioso, garantindo assim que nenhum aluno fique no pátio sem atividade. $\mathrm{O}$ custo de toda a implantação e o pagamento dos professores ficou integralmente sob a responsabilidade do Estado do Rio de Janeiro. A lei também concedeu às entidades religiosas o direito de planejar o conteúdo programático e coordenar seus professores da maneira que quisessem. Mesmo debaixo das já mencionadas críticas de muitas entidades e pessoas físicas, que entre outras coisas alegavam que há um déficit de 15.000 professores de matérias como matemática, química e física, o ensino religioso foi implantado e em 2008 está em seu quinto ano desde a aprovação da lei ${ }^{1}$.

Lei aprovada, concurso realizado e professores empossados e trabalhando em alguns dos 1882 colégios da rede pública estadual. Essa era a situação da disciplina ensino religioso em meados de 2004, que até hoje está em processo de institucionalização. Daí em diante, duas situações distintas se delinearam. De um lado, a lei confessional apoiada pela coordenação de educação religiosa da Secretaria Estadual de Educação, comandada por uma professora católica, que reforça a importância de dividir os alunos por credo e defende a legitimidade do ensino de religião, rebatendo os argumentos contrários. De um outro lado, a realidade prática dos colégios estaduais, despreparados para cumprir a lei, com deficiência infra-estrutural para acolher os professores que chegavam e buscavam se inserir no cotidiano das escolas. Profissionais que, muitas vezes, também não concordam com o caráter confessional da lei e, por isso, descumprem a orientação do seu credo.

Durante a pesquisa que desenvolvi no mestrado, procurei acompanhar as reuniões que a coordenação de educação religiosa realizava com os professores no intuito de ajudá-los com os problemas no dia-a-dia das escolas, solidificando assim a disciplina e orientando o corpo docente para um determinado tipo de trabalho. Apesar

\footnotetext{
1 As apreciações feitas sobre a implantação do ensino religioso no Estado do Rio de Janeiro foram baseadas no trabalho dos pesquisadores Emerson Giumbelli e Sandra de Sá Carneiro, que elaboraram o número 60 da revista Comunicações do ISER.
} 
dos esforços para dar coesão à disciplina, o acompanhamento das reuniões mostrou que cada professor possui um tipo de trabalho diferente do outro e que a confessionalidade estabelecida pela lei não é cumprida. A imersão dentro de um colégio estadual durante um ano letivo mostrou aspectos e resultados surpreendentes, que sem o trabalho de campo dificilmente seriam identificados. Cada professor que entra em uma escola encontra um universo bastante particular para desenvolver seu trabalho. Desta forma, o ensino religioso precisa se adaptar ao espaço e conquistar um lugar. Uma vez dentro da escola, são muitos os fatores que influenciam a disciplina e o professor. $\mathrm{O}$ primeiro desses fatores é a quase impossibilidade de cumprir o sistema confessional que a lei exige: não há como oferecer aulas para todas as demandas em todos os colégios, pois são apenas quinhentos professores. Desta forma, a maioria dos colégios conta apenas com um professor de religião. Isso obriga o professor a dar aula para uma turma heterogênea e faz com que muitos profissionais não abordem a sua doutrina. Além disso, cada corpo diretivo tem um perfil e alguns são hostis à presença de aulas de religião nas escolas públicas. Assim, o tamanho da escola, a sua infra-estrutura, o seu número de alunos, o apoio de professores de matérias tradicionais, a opinião dos pais, o grau de liberdade que determinado colégio oferece aos seus alunos, a trajetória religiosa e profissional dos professores de ensino religioso, tudo isso, muda consideravelmente os trabalhos que estão em prática e as possibilidades que a disciplina pode assumir.

As experiências de ensino religioso que acompanhei em um colégio da zona norte do Rio de Janeiro, que chamarei pelo nome fictício de Colégio Estadual Carlos Alberto (CECA), mostraram exatamente como o universo escolar modifica o que oficialmente é previsto na legislação. O professor evangélico que acompanhei elaborou um projeto de "orientação para a vida dos alunos", buscando transmitir valores morais e éticos e trabalhar temas como trabalho, sexualidade, drogas e estudo. Acolhido pela direção, demais professores e alunos, a aula de ensino religioso se apresentou como um projeto que não ensinava religião e que buscava ajudar os jovens com as suas dificuldades. $\mathrm{O}$ professor Roberto ${ }^{2}$ fazia questão de dizer aos alunos e professores que não ensinava religião e em entrevista realizada afirmou o seguinte:

Agora, eu creio que deve existir uma cadeira, uma disciplina que prepare os nossos alunos para a vida. Informações para uma formação para a vida, não uma formação acadêmica. Uma formação para vida que eu digo é o seguinte: trabalhar a ética,

2 Roberto é um nome fictício. A professora católica que acompanhei, chamarei de Márcia. 
trabalhar comportamento, trabalhar questões emocionais, questões de problemática de trabalho, de saúde, da violência, e é isso que a gente está tentando realizar com eles. Dentro dessa perspectiva, eu já vim com essas idéias dentro da minha cabeça, não vou pregar doutrina, seja qual ela for, não vou falar de religião alguma dentro da minha sala de aula, eu vou trabalhar a questão ética-comportamental, ajudar meus alunos a se entenderem, a buscarem o entendimento de si próprio, para crescerem e se desenvolverem e quem sabe se tornarem até melhores do que são, até mesmo em termos da própria formação acadêmica, em sala de aula. E fiz isso uma proposta para mim mesmo e junto aos alunos eles aceitaram, tanto é que a recepção em 2004 quando eu tomei posse junto a direção do colégio, junto aos alunos, foi excelente. Todos quiseram participar porque eu não vim discutir religião, eu vim trabalhar com eles, no sentido da máxima, da máxima de vida ${ }^{3}$.

Se o projeto na visão do professor não era religioso e não abordava sua doutrina, a motivação para realizar o concurso, entretanto, teve origem claramente religiosa, pois Roberto afirmou que recebeu um "comando divino" para implantar este projeto. Nas palavras dele: “... eu senti isso até em termos de, uma espécie, talvez você não entenda, mas um comando divino nesse sentido. Eu senti isso, eu sabia que eu ia passar, eu tinha a certeza. Eu fiz já com o intuito: 'Eu vou passar, e vou desenvolver esse trabalho'”. Tentei explorar melhor esta motivação e perguntei em uma conversa informal gravada como foi que ocorreu este "comando divino". Ele disse o seguinte:

Eu tive um insight, foi Deus que me colocou ele. (...) Porque se eu não tivesse feito isso, até mesmo influenciado outros colegas em relação a este trabalho, a gente teria criado um caos muito grande em vários colégios. (...) Então na realidade o meu trabalho foi um trabalho apaziguador. E é um trabalho divino.

Entender todas as dimensões que levaram o professor a realizar o concurso e conceber seu projeto para ser aplicado via a disciplina de ensino religioso é um pouco difícil. Contudo, durante um ano de observação, percebi que havia algo que norteava todas as idéias do professor dentro do colégio. Ele apresenta uma grande e sincera preocupação com as questões que hoje afetam e afligem a juventude. É como se ele percebesse que os adolescentes estão em uma fase rápida de mudanças e crescimento, se preparando para assumir novos papéis sociais de uma vida adulta, mas sem ninguém que os oriente para um determinado rumo, sem ninguém com quem eles possam contar para resolver seus problemas e suas angústias (Elias, 2000, p.139). A entrada na vida adulta e o enquadramento em papéis pré-estabelecidos socialmente começam, em sociedades como a nossa, exatamente na adolescência, quando surgem muitas questões

3 Quando não indicado, transcrição refere-se à entrevista realizada com o professor Roberto Mota no dia 03/05/2006. 
e escolhas que os jovens terão que enfrentar para um dia se tornarem adultos com identidade própria e socialmente integrados (Elias, 2000, p.143). E não são poucos os desafios dos jovens: precisam lidar com o desempenho escolar, com escolhas de profissão, com sua mudança de corpo e sexualidade, entrada no mercado de trabalho, relacionamento com os familiares, etc. Enfrentar tudo isso não é nada fácil. Os alunos de ensino médio hoje têm entre 14 e 18 anos de idade e são ainda muito novos para terem uma visão clara do que querem de seu futuro e de que forma vão lidar com os desafios que todo jovem vive e precisa ultrapassar.

O projeto que o professor implantou no colégio guarda muita relação com a sua maneira de enxergar as dificuldades da juventude e seu desejo de ajudá-la. Na opinião de Roberto, as famílias de hoje não estão mais em condições de orientar seus filhos e transmitir valores morais. Ele acredita que os valores devem ser passados em casa, pela família, e não é função da escola fazer isso. Mas, diante da situação em que a família "está largada", a escola pode atuar como "pronto-socorro" conjuntamente com a Igreja, outra instituição que, para o professor, transmite valores às pessoas. Esta maneira de conceber a disciplina foi capaz de extrapolar a hora-aula semanal por turma prevista na grade horária e se tornou um dos principais projetos pedagógicos do colégio. Os projetos extra-curriculares, as saídas pedagógicas, passeios e palestras na escola passaram a ser controlados pelo professor de ensino religioso, que estabeleceu ligação muito próxima com a diretora geral do colégio. A disciplina, neste colégio, pôde se expandir, se fazer presente e influenciar muitos setores da escola. Houve basicamente duas razões para que isso ocorresse. A primeira delas diz respeito ao caráter liberal e acolhedor do colégio, que ainda hoje é considerado uma das poucas boas escolas estaduais públicas da cidade e que tem como característica valorizar o diálogo entre professores, alunos e direção, além de permitir a liberdade de expressão - o que facilitou bastante a entrada e adaptação do professor evangélico, que afirmou nunca ter sofrido a rejeição que alguns professores de ensino religioso contam ter ocorrido. A outra razão se refere à forma como o projeto chamado de "fórum permanente de estudos juvenis" foi elaborado, ou seja, sua apresentação como um projeto não religioso, apesar de ter claramente finalidades religiosas no seu conteúdo. A "orientação para a vida" que o projeto propõe ao abordar temas importantes para a juventude permite que o "fórum" seja percebido por alunos, professores e pais como uma aula que não ensina religião, apesar do professor líder do projeto ser um pastor evangélico ligado à Igreja Batista, das aulas terem conteúdo religioso e do professor Roberto realizar, ao final de cada aula, 
uma prece com os alunos. Esta oração não tem dizeres que necessariamente se repetem, o professor geralmente pede a Deus que abençoe e proteja os alunos. Um exemplo representativo de prece é o seguinte:

Senhor, tome a vida destes jovens nas Tuas mãos, que possa estar abençoando tanto a eles quanto as suas famílias. Que eles possam se despertar para as áreas, infinitas áreas, que eles possam crescer, aprender o que é importante para a vida deles. Toma as suas vidas nas Tuas mãos, abençoe-os, livra-os do mal, que eles possam entender a Tua vontade e praticá-la em suas vidas. Tenham uma semana abençoada na Tua presença. Deus abençoe vocês, uma boa semana. Até semana que vem.

Como pode uma aula ser reconhecida como não religiosa, mas apresentar vários aspectos religiosos, como, por exemplo, a oração? Como esta construção de idéias é possível? O professor tem muita habilidade com os diferentes atores do colégio, o que permite que o "fórum" tenha uma aparência não religiosa. Essa habilidade ficou clara em uma entrevista, quando perguntei o que acontecia com os alunos que se recusavam a participar das aulas de ensino religioso, o que, reforço, é direito garantido por lei. Ele respondeu o seguinte:

$\mathrm{Na}$ época eles nem apareciam no colégio. Um ou outro ficava lá fora, mas eram poucos alunos, no máximo dois alunos de cada turma ficavam lá fora. Às vezes era até casal de namorados, era pouca gente. Hoje, na realidade, com esse projeto, acaba o problema. Esse projeto se torna a opção que o colégio tem que ter para dar no lugar do ensino religioso. Então eles são obrigados a participar agora. Agora eles são obrigados a participar, então não pode ninguém... Eu não obrigo eles a participarem. Mas eles, nesse caso, vamos dizer assim, ensino religioso em sala de aula, entendeu a questão? Se você formaliza um projeto que é exatamente a opção ao ensino religioso, eles têm que participar. Entendeu? Não é obrigatório, não é reprovatório. Não reprova. Mas, na realidade eles são obrigados a participar como uma forma de atividade. Por isso que eu não faço nenhuma avaliação mais.

Com essa construção de ser obrigatório, mas ninguém ser forçado a participar, podemos perceber como funciona a apresentação do "fórum" dentro da escola. O professor diz não ensinar religião, mas em uma entrevista reconheceu que ensina; fala que eles são obrigados a participar, mas ele não os obriga; diz aos professores que não ligou a disciplina com a sua religiosidade, mas as aulas que acompanhei deixam claro que há muitas referências a Deus e a sua crença evangélica. Desta maneira, Roberto consegue evitar muitos obstáculos e o "fórum permanente de estudos juvenis" pode progredir desimpedido, sem as oposições que fatalmente surgiriam caso o ele dissesse que ensinaria religião. O estabelecimento do professor e do "fórum" se deve então, em 
parte, ao ambiente do Colégio Carlos Alberto. Por outro lado, é essa construção de idéias que sustenta o "fórum" e que permite o projeto fluir livremente como se nada tivesse de religioso. Se Roberto tivesse chegado ao colégio sem o discurso de que é contrário ao ensino religioso, sem dizer que não ensina religião, sem o projeto de "orientação para a vida", talvez jamais conseguisse o espaçou que conquistou. Creio que foi necessário que a religião não aparecesse em primeiro plano para consolidar o projeto e conquistar um espaço.

A professora católica que acompanhei, além de possuir uma trajetória profissional e religiosa bem distinta do professor evangélico, tomou posse como professora em um colégio em Duque de Caxias $(\mathrm{RJ})$ e lá trabalhou por quase três anos. Quando perguntei sua motivação para realizar o concurso, Márcia deu uma resposta surpreendente e bem diferente do outro professor:

Porque eu precisava trabalhar. Aí foi... eu vou ser bem sincera. Eu estava sem trabalhar, né? Só estudando e... eu comecei a ver que a grana tava curta. Um filho de... meu filho na época tinha uns dezessete anos, sabe? Muita despesa, aí eu falei: 'Não! Tem que trabalhar, só o dinheiro do meu marido não dá, pô!'. Aí, fui trabalhar.

A surpresa ocorreu porque esperava uma resposta semelhante a do professor evangélico, algo que ao menos estivesse relacionado a sua fé. Entretanto, foi a questão financeira o fator determinante que a motivou. A escola em que inicialmente trabalhou era pequena, com poucos professores e alunos, sem infra-estrutura adequada e sem praticamente nenhum espaço para os alunos ficarem à vontade nos intervalos e recreio. Era um colégio estadual que atendia desde o $6^{\circ}$ ano do ensino fundamental até o $3^{\circ}$ ano do ensino médio. Devido à orientação da direção da escola, Márcia não podia dizer aos alunos que o ensino religioso era facultativo, o que tornou a disciplina obrigatória neste colégio. Alegando que não havia onde deixar os alunos que optassem por não freqüentar as aulas de religião e que não havia possibilidade de oferecer outra atividade, o colégio decidiu que todos iriam comparecer às aulas, independentemente de serem ou não católicos. A professora católica, por convicção própria, já evitava aulas que pudessem causar conflito entre os credos e ao usar referências da sua doutrina, sempre procurava mostrar que a visão católica não é a única. Ela também realizava uma prece no final de cada aula, mas apenas até o $8^{\circ}$ ano do ensino fundamental. Os alunos liam junto com a professora a seguinte oração: "Senhor, aqui estamos reunidos em teu nome. Ajuda-nos a 
não desanimar nas horas difíceis. Ensina-nos a confiar em ti. Queremos viver sempre junto a ti. Fica sempre conosco, Senhor! Amém!”.

Ao sair do colégio em Duque de Caxias e ingressar na escola no Rio, na qual fazia o acompanhamento, a concepção de ensino religioso desta professora foi, aos poucos, sofrendo novas adaptações: ela encontrou um colégio grande e liberal da rede pública, com pouco menos de três mil alunos, funcionando nos turnos da manhã, tarde e noite, com ensino médio e pós-médio (administração). Além da maior liberdade para desenvolver seu trabalho, como já havia um professor evangélico trabalhando lá, a professora teve que procurar o seu espaço para que dois professores pudessem conviver na mesma escola. A solução foi simples: a professora católica abriu mão de seu trabalho de ensino religioso e desde 2007 adota o projeto de "orientação à juventude". Antes, suas aulas eram repletas de referências religiosas, ensinando aos alunos a história de Jesus e dos líderes mundiais que seguiram seus ensinamentos, abordando a polêmica das células tronco e a questão do aborto vista sob a perspectiva religiosa, indicando aos alunos passagens bíblicas para ajudá-los quando eles enfrentam algum tipo de dificuldade, etc. Com a sua inserção no projeto que já estava vigente, suas aulas sofreram novas mudanças, o que mostra que, além da influência que uma escola exerce no trabalho de ensino religioso, a presença de outro credo ou professor de religião também pode alterar a concepção que um professor tem da disciplina.

A implantação do ensino religioso, conforme já mencionei, gerou dois discursos: um deles refere-se ao posicionamento oficial da coordenação de educação religiosa da Secretaria Estadual de Educação, que apóia o que está previsto na lei; o outro discurso se refere aos professores dentro das escolas, lugar onde o ensino religioso é, de fato, produzido junto com alunos e comunidade escolar, onde penso que as questões mais interessantes aparecem. Entretanto, é um engano pensar que a lei que regulamentou o ensino religioso trouxe a religião para dentro da escola pública. Na realidade, o tema religião e escola pública independe da disciplina ensino religioso. Mas, muitas pessoas acreditam que a relação entre religião e escola no Estado do Rio de Janeiro inicia apenas recentemente com o ensino religioso, como se antes a religião não estivesse presente no cotidiano escolar. O trabalho etnográfico ajuda a esclarecer este mal entendido, provando que a religião está permanentemente dentro dos colégios. Sem dúvida, o ensino religioso se apresenta de maneira oficial e regulamentada por lei. Isso, no entanto, não deve nos impedir de enxergar que a relação entre religião e escola pública vai muito além de uma disciplina que somente a partir de 2004 começou a ser oferecida 
por professores contratados especificamente para desempenhar esta função - antes disso, os professores que ensinavam religião tinham matrículas de outras disciplinas e trabalhavam por conta de deslocamentos. A escola que acompanhei, por exemplo, possui uma pequena capela dentro de sua infra-estrutura e realiza missas com padres no decorrer do ano letivo, para celebrar datas como o aniversário do próprio colégio e o dia das mães. Durante o ano que lá estive, vi alguns murais feitos com referências diretas à Deus. Além disso, como não poderia deixar de ser, há pessoas com os mais diferentes graus de religiosidade na escola. A diretora adjunta da manhã, neste colégio da zona norte do Rio de Janeiro, no dia em que nos conhecemos fez questão de me mostrar sua "santinha" na mesa de trabalho e disse ser católica e devota da santa. Os próprios estudantes demonstraram ter religiosidade em algumas situações que presenciei.

\section{CONSIDERAÇÕES SOBRE A RELAÇÃO ENTRE RELIGIÃO E MODERNIDADE}

Estudar a relação entre religião e escola pública levanta muitas questões, algumas de caráter mais abrangente, que buscam fortalecer as teorias acadêmicas que norteiam as pesquisas na área de antropologia, sociologia e ciência política, outras de caráter específico, que procuram compreender uma determinada situação particular restrita ao objeto em questão. Para compreender o caso exposto, algumas correntes teóricas podem ser de grande valia. Tentarei aqui apresentar um argumento da ciência política e outro que acredito que possa ser classificado como sociologia da religião.

A noção de que o lugar da religião é longe de qualquer esfera pública parece estar consolidada e enraizada no pensamento das pessoas em geral. É comum a associação de que a religião no espaço comum pode causar guerras, conflitos e perseguições, abalando a estabilidade pública (Bader, 1999:598). Há, sem dúvida, razões históricas para se pensar desta maneira. Não cabe aqui aprofundar estes episódios ou tentar construir argumentos a favor ou contra a atuação religiosa no meio público de uma república que se apresenta como neutra e, portanto, não religiosa. Contudo, há uma ampla discussão da ciência política sobre o estatuto da presença religiosa no espaço público e creio que apresentá-la com brevidade é interessante.

A religião na escola provoca reações de aversão porque, entre outras coisas, rompe com a crença comum de que religião e Estado devem permanecer separados para que haja imparcialidade. O princípio que estabelece a neutralidade do Estado, formulado pela teoria liberal, consiste em afastar do jogo político e da esfera pública muitas das esferas particulares às quais os cidadãos são participantes ou têm apego 
sentimental. Segundo John Rawls, um dos principais teóricos do liberalismo contemporâneo, para promover a cooperação entre os indivíduos e promover um sistema justo e capaz de proporcionar a convivência é preciso que as chamadas "doutrinas abrangentes" estejam fora do cenário público. Nas palavras do autor, "As doutrinas abrangentes de todos os tipos - religiosas, filosóficas e morais - fazem parte do que podemos chamar de "cultura de fundo" da sociedade civil. É a cultura do social, não do político" (Rawls, 2000:56). Os indivíduos podem manter suas particularidades e têm liberdade para praticar suas ações, desde que na esfera pública renunciem a seus gostos particulares. Ao afastar todas as doutrinas abrangentes, o Estado alega ser imparcial e justo diante de todos os cidadãos. De acordo com essa construção da teoria liberal, a religião fica definitivamente afastada de qualquer possibilidade oficial ou legal de atuar na esfera pública, restrita apenas à vida privada de cada um. Esse lugar não é somente reservado à religião, mas, teoricamente, a todas as demais concepções de mundo e estilos de vida.

Assim, quando o fenômeno religioso surge nas escolas, os debates entre aqueles que sustentam a possibilidade de presença da religião no espaço público e os que rejeitam esta mesma possibilidade vêm à tona. Os que a defendem, como Stephen Carter, autor de The culture of disbelief, chamam a atenção para a grande importância que a religião tem na vida particular das pessoas, servindo como guia moral e de conduta nas mais diferentes ações. É também comum um ataque ao suposto caráter de neutralidade que a teoria liberal alega possuir. Para alguns autores, a imparcialidade do Estado não existe e a conceituação de que o Estado é neutro mascara um preconceito contra a religião ao impedi-la de se manifestar (Carter, 1994, p.13). O afastamento da religião dos debates públicos se torna assim uma situação de injustiça com as religiões e seus fiéis (Bader, 1999, p.608). Contudo, os que são contrários à presença da religião no público, como Stephen Macedo (1998), admitem que o Estado laico não é neutro, mas ainda assim acreditam que a religião deve ser mantida afastada do espaço público, principalmente dos colégios, uma vez que estes têm a função de abrigar estudantes de diversas raças, classes e religiões para moldá-los como seus futuros cidadãos com valores e comprometimentos básicos que devem ser compartilhados por todos. Além disso, ainda segundo Macedo (1998), é preciso homogeneizar os cidadãos com alguns conceitos para que a diversidade possa conviver, já que a ordem liberal que pressupõe indivíduos livres e cooperativos que aceitam a diferença é uma conquista política. 
Este debate de teoria política que visa permitir ou não a atuação da religião na esfera pública fica bastante acirrado quando o campo de disputa é a escola. Isso ocorre por diversas razões, como a importante função da educação em formar as novas gerações e construir suas crenças e comprometimentos. Além disso, o sistema de educação mantém estreita ligação com a sociedade em que se insere, cabendo ao colégio complementar coerentemente a educação transmitida pela família e pela sociedade de maneira geral. A religião na escola suscita problemas por se inserir exatamente em um meio que, por natureza, irá influenciar o pensamento de toda uma geração, podendo alterar consideravelmente a forma de pensar de boa parte da sociedade no futuro. Na sociedade de hoje, o sistema de educação tem uma enorme força e qualquer alteração no sistema público de ensino pode resultar em grande mudança social no futuro. Talvez seja por isso que o caso do ensino religioso tenha provocado tanta preocupação, especialmente por parte dos estudiosos.

Toda a discussão acadêmica da teoria liberal sobre a separação entre Igreja e Estado, a compatibilidade legal da religião com os Estados laicos e, também, do caráter positivo ou negativo desta possível relação, nos impede, muitas vezes, de perceber que a separação não se realiza plenamente na prática cotidiana. Há, no projeto da modernidade, um lugar para a religião na esfera privada e um afastamento do domínio público. Entretanto, podemos perceber, no dia-a-dia, a clara presença da religião nas diversas esferas públicas. A questão da religião na escola é um exemplo concreto de manifestação e atuação do religioso no público. Assim, se deixarmos um pouco de lado a discussão da ciência política, pois, afinal de contas, ela propõe soluções para questões de caráter imediato e restrito a uma dada sociedade (Geertz, 2001, p.191), perceberemos que o estudo da religião como força cultural e social que atua e influencia numa construção de mundo, relacionando-se com as demais instituições que também exercem semelhante influência, pode proporcionar uma análise bem mais interessante do que a feita pela teoria política. É uma análise que busca perceber a relação entre religião, modernidade e a emergência de forças seculares que obrigam a religião a ganhar novo posicionamento no mundo moderno e a atuar de uma nova maneira. Esta configuração, na qual a religião ganha novo lugar, desta vez em um mundo não mais visto sob uma perspectiva religiosa, mas sim secular (Casanova, 1994, p.15), suscita muitas questões que podem ser pensadas a partir do tema religião e escola e que colaboram para a compreensão da teoria da secularização e dos debates em torno desta teoria. O conceito de secularização, segundo Peter Berger, é: 
... o processo pelo qual setores da sociedade e da cultura são subtraídos à dominação das instituições e símbolos religiosos. Quando falamos sobre a história ocidental moderna, a secularização manifesta-se na retirada das Igrejas cristãs de áreas que antes estavam sob seu controle ou influência: separação da Igreja e do Estado, expropriação das terras da Igreja, ou emancipação da educação do poder eclesiástico... (Berger, 1985, p.119).

Para alguns autores, como o próprio Berger (2001) e José Casanova (1994), muitos trabalhos produzidos sobre a teoria da secularização, que previam um recuo das religiões, estavam equivocados, pois o mundo hoje "é tão ferozmente religioso quanto antes, e até mais em certos lugares" (Berger, 2001, p.10). Por muito tempo, acreditou-se que, com o avanço da modernidade, haveria um declínio da religião nas suas manifestações públicas e na mentalidade das pessoas (Berger, 1985, p.10). Conceitos de secularização como o de Berger levaram muitos estudiosos a pensar em sub-teses da teoria da secularização, fazendo previsões para o fenômeno religioso. Previu-se não somente o declínio da religião, como também um processo de privatização e marginalização, podendo chegar inclusive ao seu total desaparecimento ${ }^{4}$ (Casanova, 1994, p.20). Temas como a oposição entre religião e razão ou entre religião e ciência eram recorrentes e apontavam na direção de enxergar a modernidade e a religião como incompatíveis (Berger, 2001). Tal visão, no entanto, reproduzia a percepção de história como um processo evolucionário que leva da superstição à razão, da religião à ciência, como se a humanidade caminhasse para uma direção já determinada, envolvida em um enredo com alguma finalidade última (Giddens, 1990), no qual a religião estaria condenada a desaparecer. Como o avanço da modernidade, trazendo a urbanização, industrialização e educação prioritariamente científica, não acarretou o declínio da religião, tornou-se necessário repensar algumas questões que antes, devido a um consenso entre muitos pesquisadores (Berger, 2001), pareciam já estar resolvidas.

A modernidade se espalhou pelos diferentes países de diversas maneiras. Junto com ela, espalharam-se também as diferentes instituições que a compõem, o que inclui obviamente a religião. Houve explosão religiosa em algumas partes do mundo, como é o caso do crescimento evangélico na América Latina (Berger, 2001), e manifestações públicas da religião que chamaram a atenção dos pesquisadores pela sua grandiosidade e capacidade de influenciar. Tornou-se preciso, então, estudar os fenômenos religiosos sem esse olhar de incompatibilidade ainda hoje existente em algumas teorias

$4 \quad$ A idéia de desaparecimento da religião não é do autor, apenas é exposta por ele. 
acadêmicas quando se pensa na relação com a modernidade e na atuação no espaço público. Não se trata nem de aceitar ou descartar a teoria da secularização completamente, mas sim de perceber o que é válido e o que se mostrou estar errado.

Diante das manifestações religiosas na esfera pública, foi necessário estudar uma determinada situação levando em conta que a separação entre Igreja e Estado, por exemplo, não ocorreu plenamente e que o fenômeno religioso não deixou de se manifestar no público. Afastada a idéia de incompatibilidade entre religião e modernidade, indagou-se de que formas o mundo moderno pôde, ao contrário do que se pensava, permitir florescer movimentos religiosos em vários países, regiões e continentes. Como afirma Berger, "a modernidade, por razões muito compreensíveis, solapa todas as velhas certezas; a incerteza é uma condição que muitas pessoas têm grande dificuldade em assumir; assim, qualquer movimento (não apenas religioso) que promete assegurar ou renovar a certeza tem um apelo seguro" (Berger, 2001, p.14). Então, ao invés de pensar em um projeto de modernidade que, aos poucos, eliminou a religião, tornou-se mais realista aceitar e reconhecer a religião como fenômeno que continua presente, inclusive na esfera pública, e com grande força. Houve, segundo Berger (2001), deslocamento de lugar da religião e perda de plausibilidade na argumentação no espaço público, o que ocorreu principalmente na Europa Ocidental. Mas, a idéia de total afastamento não corresponde à realidade que podemos hoje verificar. $\mathrm{Na}$ verdade, devemos perceber nos dias de hoje a religião como uma instituição importante e que está presente no mundo cotidiano, provavelmente em todas as esferas sociais. Isto significa reconhecer a construção marcadamente religiosa do mundo em que vivemos, com possibilidade de expressão na esfera pública, sem que isso nos deixe com a impressão de que a religião está fora de seu lugar (Casanova, 1994, p.39).

\section{CONSIDERAÇÕES FINAIS}

$\mathrm{O}$ caso do ensino religioso nos fornece bastante material para pensarmos sobre muitas questões já levantadas. O trabalho etnográfico desenvolvido ao longo de um ano escolar ajuda, por um lado, a fortalecer as teorias acadêmicas que norteiam as pesquisas na área de religião. Por outro lado, a imersão na escola e o acompanhamento da aula de ensino religioso proporcionam o entendimento de uma situação específica. Somente o estudo de caso pode realmente revelar o que acontece. A presença semanal no colégio e a relação de proximidade e informalidade desenvolvida com Roberto, Márcia e alguns 
alunos permitem alcançar os objetivos de pensar em uma teoria geral e aprofundar a compreensão de uma situação particular. Só a convivência no colégio permitiu enxergar e entender as adaptações que a disciplina ensino religioso sofreu em relação ao que estava previsto na lei. A pluralidade de credos, a situação infra-estrutural das escolas públicas e a comunidade afetam diretamente o tipo de trabalho que pode ser desenvolvido, impossibilitando muitas vezes o caráter confessional da legislação e provocando uma incontável variedade de práticas e maneiras de conceber e vislumbrar o ensino religioso. Apesar da orientação da coordenação de educação religiosa e da sensibilidade do núcleo dirigente para diminuir as dificuldades dos professores, os obstáculos ainda são inúmeros. Em parte, por causa disso, há uma diversidade na condução da disciplina.

No Colégio Estadual Carlos Alberto o ensino religioso se apresentou de uma maneira peculiar: ao invés de uma aula de religião doutrinária, o "fórum permanente de estudos juvenis" procura transmitir valores morais e éticos através de uma orientação para a vida do jovem. Apesar da aparência não religiosa, o "fórum" tem motivações e finalidades religiosas, ligadas, inclusive, à fé e à religião do professor. Na verdade, a apresentação não religiosa do "fórum" nos permite pensar exatamente na discussão teórica da mudança de posição do religioso e sua perda ou não de influência no mundo moderno. Um projeto religioso provavelmente sofreria oposições na escola e teria dificuldades de justificar os temas que propõe discutir. Contudo, sem a religião em primeiro plano, o "fórum" se tornou o principal projeto do colégio, com boa influência no corpo diretor. Dessa forma, a religião está lá, dentro das aulas, nos passeios, na reunião de professores e na tomada de decisões da direção. Sua presença vai muito além do tempo semanal por turma destinado à disciplina. As aulas de Roberto mostraram muitas referências ao religioso: a oração foi um exemplo constante disso. Entretanto, houve outras referências episódicas, como conversas sobre sua vida particular nas quais ele fala de sua igreja e faz referências à Bíblia.

Na mesma escola foi possível acompanhar um outro tipo de trabalho, de outro credo e, em uma primeira abordagem, com outros objetivos. A professora Márcia trouxe para o CECA o trabalho que realizava no colégio em Duque de Caxias. Repleto de referências religiosas, a aula de ensino religioso de Márcia parecia propor algo completamente diferente da de Roberto. Sem dúvida, nas aulas de Márcia a religião aparece em primeiro plano quando a professora conta a história de Jesus, dos líderes mundiais que seguiram seus ensinamentos, da polêmica com as células tronco e o 
aborto, das passagens bíblicas que ensina a consultar, etc. No entanto, numa análise mais cuidadosa, percebi que havia muita semelhança de idéias entre os dois professores: ambos procuravam servir de referência para seus alunos, falavam sobre as escolhas, conseqüências das escolhas, dos valores morais e éticos, das virtudes e da situação no mundo de hoje de todos quererem "usurpar" ou "se dar bem" diante do próximo. É importante destacar as idéias comuns, pois, às vezes, damos valor demais às diferenças e esquecemos de olhar para as semelhanças, aquilo que une Roberto e Márcia em uma mesma causa.

Não me restrinjo apenas aos dois professores do CECA. Acredito ser fundamental olhar para os outros quase quinhentos concursados. Muitos deles falam nos valores morais e éticos, na violência e nas virtudes. O olhar sensível que Roberto tem em relação às questões da juventude e sua vontade de ajudá-los estão presentes também nos discursos de Márcia e de vários outros professores com os quais conversei. Sempre notei muita vontade de ajudar por parte dos professores de ensino religioso. Apesar das críticas, muitos deles, realmente, querem colaborar para tentar melhorar a vida dos alunos e a situação de abandono da escola pública. São pessoas religiosas que, como qualquer outra pessoa, são sensíveis e solidárias às dificuldades dos jovens de escola pública e desejam ajudar de alguma maneira. No entendimento deles, o ensino da religião colabora para resolver problemas e mudar a realidade que hoje está em vigor. Há razões para concordar ou não com a religião na escola e, de forma geral, na esfera pública. Há diferenças na forma de pensar sobre os mais variados assuntos. Mas, se fizermos o esforço de esquecer as diferenças, mesmo por um momento apenas, e nos concentrarmos naquilo que temos em comum, perceberemos que a semelhança muitas vezes é bem maior do que aquilo que nos difere. Religiosos ou não, favoráveis ou não ao ensino religioso, guardamos em comum muito mais do que normalmente percebemos: a maioria quer ajudar os alunos, orientá-los, resolver os sérios problemas estruturais da educação pública. O "fórum" do professor Roberto e o trabalho de Márcia são dois exemplos que buscam atuar dentro da escola, comprometidos com os alunos e com o espaço, diferentemente de muitos professores de matérias tradicionais que dão a sua aula e saem sem se preocupar com os estudantes e com o lugar. É claro que, como professores de ensino religioso, eles irão propor projetos e formas de colaborar de acordo com a sua formação religiosa, vivência, entendimento de mundo e percepção de realidade. Isso é o que todos nós fazemos. Para ajudar jovens que muitas vezes não contam com a família, não sabem que profissão escolher ou estão incertos com alguma 
questão típica da juventude, Roberto elaborou o "fórum permanente de estudos juvenis", que tem motivações, referências e fins religiosos, pois é assim que ele enxerga o mundo em que vive. Um outro profissional, de outra área, provavelmente realizaria outro trabalho diante das mesmas questões. Mas, as questões, os jovens e os problemas da escola estão lá. E há um grande número de pessoas sensíveis a estas situações e que gostariam de cooperar, atuar. Não se trata então de discutir se a religião pode ou não ocupar o espaço público, se deve ou não estar na escola - ela já está, sempre esteve. Trata-se, antes de tudo, de perceber a presença religiosa e a maneira pela qual se estabelece, atua, constrói argumentos e influencia no comportamento e visão de mundo das pessoas. É claro que a discussão normativa e política sobre a presença religiosa no público é importante, desde que não nos atrapalhe a perceber a realidade ao nosso redor.

Além disso, como já comentei, é importante procurarmos dar destaque também às semelhanças, aos nossos objetivos comuns, pois, somente assim, podemos diminuir a importância que damos às nossas divergências e começar a valorizar o que compartilhamos. No caso aqui em questão, os projetos de Roberto e Márcia, mesmo de teor religioso, tocam em um ponto - orientação à juventude - que uma grande quantidade de pessoas julga ser necessário. Não proponho que se esqueça que é um projeto religioso ou, em última análise, que se esqueça a diferença entre aqueles que querem abordar uma mesma questão de outra maneira. As diferenças de idéias existem, às vezes são inconciliáveis. Entretanto, não podemos permitir que as divergências nos impeçam de enxergar os objetivos que muitas vezes temos em comum. $\mathrm{O}$ ensino religioso nos colégios públicos pode adquirir várias formas e objetivos. Parece-me que a vontade de ajudar os alunos, tão bem expressada no "fórum", é uma idéia compartilhada por muitos professores desta disciplina. E não só por eles, mas também por muitos de nós.

\section{REFERÊNCIAS:}

BADER, Veit. "Religious pluralism. Secularism or priority for democracy?". Political Theory, 27 (5), 1999: 597-633.

BARTH, Fredrik. "A análise da cultura nas sociedades complexas". In: O guru, o iniciador e outras variações antropológicas. (org) Lask, Tomke. Rio de Janeiro, Contracapa, 2000.

BERGER, Peter L. O dossel sagrado. São Paulo: Paulus 1985. 
BERGER, Peter L. A dessecularização do mundo: uma visão global. Religião e Sociedade, 21 (1), 2001: 9-23

CARNEIRO, Sandra de Sá. Religião nas escolas: comparação entre Brasil e EUA. $25^{\mathrm{a}}$ Reunião Brasileira de Antropologia. Publicação eletrônica. 2006

CARTER, Stephen L.. The culture of disbelief: how American law and politics trivialize religious devotion. New York: Anchor Books, 1994.

CASANOVA, José. Public religions in the modern world. Chicago: The University of Chicago Press, 1994.

DURKHEIM, Èmile. Educação e sociologia. São Paulo: Melhoramentos, 1978.

ELIAS, Norbert. Os estabelecidos e os outsiders: sociologia das relações de poder a partir de uma pequena comunidade. Rio de Janeiro: Jorge Zahar Editor, 2000.

GEERTZ, Clifford. Nova luz sobre a antropologia. Rio de Janeiro: Jorge Zahar, 2001.

GIDDENS, Anthony. As conseqüências da modernidade. São Paulo: Editora UNESP, 1991.

GIUMBELLI, Emerson. O fim da religião: dilemas da liberdade religiosa no Brasil e na França. São Paulo: Attar Editorial, 2002.

GIUMBELLI, Emerson. Religião, Estado, modernidade: notas a propósito de fatos provisórios. In: Estudos Avançados 18 (52). 2004.

GIUMBELLI, Emerson. (Org.) ; CARNEIRO, Sandra de Sá (Org.) . Ensino Religioso no Estado do Rio de Janeiro - registros e controvérsias. Rio de Janeiro: ISER, 2004. v. 1. $156 \mathrm{p}$.

GALEOTTI, Anna Elisabetta. "Citizenship and equality: the place for toleration". Political Theory, 21 (4), 1993, p. 585-605.

LOCKE, John. Carta acerca da tolerância; in Col. Pensadores. Abril Cultural, 1973.

MACEDO Stephen. "Transformative constitutionalism and the case of religion.

Defending the moderate hegemony of liberalism". Political Theory, 26 (1), 1998: 56-80.

MORUZZI, Norma. "A problem with headscarves. Contemporary complexities of political and social identity". Political Theory, 22 (4), 1994, p. 653-672.

RAWLS, John. O Liberalismo político. São Paulo: Ática Editora, 2000 [1993]. 